\title{
FLORA OF NORTH AMERICA (FNA) SCHEDULED PUBLICATION OF VOLUMES INCLUDING SASKATCHEWAN VASCULAR PLANT FAMILIES
}

VERNON L. HARMS, Emeritus Professor of Botany, 212-115 Keevil Cres., Saskatoon, SK S7N 4P2

Most Saskatchewan naturalists with botanical interests are likely well aware of the on-going Flora of North America (FNA) project, in progress for the last two decades. The following represents an abbreviated and unofficial progress report of this major collaborative project, indicating those volumes already published, and anticipated publication dates for future FNA volumes. Also given is a list of the Vascular Plant families in Saskatchewan included in each FNA volume.

The Flora of North America (FNA) project is a cooperative program involving botanists from across North America to produce a comprehensive account of the plants of North America. It is intended to serve both as a means of identifying plants, and as a synoptic synthesis or conspectus of the North American flora. The present ongoing FNA project was initiated in the early to mid-1980s, as successor to an earlier but aborted attempt of the mid-1960s and 1970s to then produce a more computerized flora. The present FNA project has been a massive collaborative endeavor involving the efforts of hundreds of North American botanists, using multiple authors, multiple taxonomic and regional reviewers, and multiple editors. What was envisioned in 1987 to be a flora of 12 volumes to be completed by $2000,{ }^{1}$ has now expanded into a planned 26 volumes for vascular plants, plus three for Bryophytes, and a time-span for its production now anticipated to extend to the year 2011. The publication order of the FNA volumes is not numerically sequential. $^{2}$

With regard to FNA coverage of the major groups of vascular plants, the treatments of Fern Allies, Ferns and Gymnosperms were completed in 1993 with the publication of Volume 2. Treatments of the monocotyledonous angiosperm families, spanning five FNA volumes (Vols. 22-26), are now nearing completion with the imminent publication of Volume 24, completing the coverage of the grass family. With regard to coverage of the dicotyledonous angiosperms, six volumes (Vols. 3, 4, 5, 19, 20 \& 21) have been published, another (Vol. 7) is imminent, and three (Vols. 6, 8 \& 9) appear well in progress to nearing completion. This leaves as outstanding nine additional volumes (Vols.10-18). 
Below are listed the 26 scheduled FNA volumes covering vascular plants, with their publication dates (actual or anticipated) and the plant families in Saskatchewan that are included in each volume. ${ }^{2}$

Volume 1: Published in 1993. Introduction: Including history of FNA, climate, physiography, soils, paleoclimates, paleovegetation, paleofloras, contemporary vegetation, phytogeography, taxonomic botany and floristics, weeds, ethnobotany, economic botany, plant conservation, classification concepts and systems, and overview of plant families.

Volume 2: Published in 1993. Includes the following SK groups and families: Pteridopytes: Lycopodiaceae (Club-moss Family); Selaginellaceae (Spike-moss Family); Isoëtaceae (Quillwort Family); Equisetaceae (Horsetail Family); Ophioglossaceae (Grape-Fern Family); Pteridaceae (Brake-Fern Family); Thelypteridaceae (Marsh-Fern Family); Dryopteridaceae (Wood-Fern Family); Polypodiaceae (Polypody Family); Marsileaceae (Water-Clover Family). Gymnosperms: Pinaceae (Pine Family); Cupressaceae (Cypress Family).

Volume 3: Published in 1997. Includes the following SK families: Nymphaeaceae (Water-Lily Family); Ceratophyllaceae (Hornwort Family); Ranunculaceae (Buttercup Family); Berberidaceae (Barberry Family); Papaveraceae (Poppy Family); Fumariaceae (Fumitory Family); Ulmaceae (EIm Family); Cannabaceae (Hemp Family); Urticaceae (Nettle Family); Myricaceae (Bayberry Family); Fagaceae (Beech Family); Betulaceae (Birch Family).

Volume 4: Published in 2003. Includes the following SK families:
Nyctaginaceae (Four-o-clock Family); Cactaceae (Cactus Family); Chenopodiaceae (Goosefoot Family); Amaranthaceae (Pigweed Family); Portulacaceae (Purslane Family).

Volume 5: Published in 2002. Includes the following SK families: Caryophyllaceae (Pink Family); Polygonaceae (Buckwheat Family); Plumbaginaceae (Leadwort Family).

Volume 6: Publication scheduled for 2007. Includes the following SK families: Elatinaceae (Waterwort Family); Clusiaceae (St. John's-wort Family); Malvaceae (Mallow Family); Sarraceniaceae (Pitcher-plant Family); Droseraceae (Sundew Family); Cistaceae (Rockrose Family); Violaceae (Violet Family); Cucurbitaceae (Cucumber Family); Loasaceae (Evening-Star Family).

Volume 7: Publication was scheduled for 2006 / 2007. Includes the following SK families: Salicaceae (Willow Family); Capparaceae (Caper Family); Brassicaceae (Mustard Family); Resedaceae (Mignonette Family).

Volume 8: Publication scheduled for 2007. Includes the following SK families: Empetraceae (Crowberry Family); Ericaceae (Heath Family); Pyrolaceae (Wintergreen Family); Monotropaceae (Indian-pipe Family); Primulaceae (Primrose Family); Grossulariaceae (Currant Family); Crassulaceae (Stonecrop Family); Saxifragaceae (Saxifrage Family).

Volume 9: Publication scheduled for 2007. Includes the following SK family: Rosaceae (Rose Family).

Volume 10: Publication scheduled for 2008. To include the following SK family: Fabaceae (Pea Family) in part. 
Volume 11: Publication scheduled for 2008. To include the following SK families: Fabaceae (Pea Family) in part; Elaeagnaceae (Oleaster Family); Haloragaceae (Water-Milfoil Family); Lythraceae (Loosestrife Family); Onagraceae (Evening-Primrose Family).

Volume 12: Publication scheduled for 2009. To include the following SK families: Cornaceae (Dogwood Family); Santalaceae (Sandalwood Family); Viscaceae (Mistletoe Family); Celastraceae (Staff-tree Family); Euphorbiaceae (Spurge Family); Rhamnaceae (Buckthorn Family); Vitaceae (Grape Family); Linaceae (Flax Family); Polygalaceae (Milkwort Family).

Volume 13: Publication scheduled for 2010. To include the following SK families: Aceraceae (Maple Family); Anacardiaceae (Sumac Family); Oxalidaceae (Wood-Sorrel Family); Geraniaceae (Geranium Family); Balsaminaceae (Jewelweed Family); Araliaceae (Ginseng Family); Apiaceae (Carrot Family).

Volume 14: Publication scheduled for 2011. To include the SK families: Gentianaceae (Gentian Family); Apocynaceae (Dogbane Family); Asclepiadaceae (Milkweed Family); Solanaceae (Nightshade Family); Convolvulaceae (Morning-glory Family); Cuscutaceae (Dodder Family); Menyanthaceae (Buckbean Family).

Volume 15: Publication scheduled for 2009. To include the SK families: Polemoniaceae (Phlox Family); Hydrophyllaceae (Waterleaf Family); Boraginaceae (Borage Family).

Volume 16: Publication scheduled for 2009. To include the SK families: Verbenaceae (Vervain Family);
Lamiaceae

(Mint

Family);

Hippuridaceae (Mare's-Tail Family); Callitrichaceae' (Water-Starwort Family); Plantaginaceae (Plantain Family); Oleaceae (Olive Family).

Volume 17: Publication scheduled for 2010. To include the following SK families: Scrophulariaceae (Figwort Family); Orobanchaceae (Broomrape Family).

Volume 18: Publication scheduled for 2011. To include the SK families: Pedaliaceae (Sesame Family); Lentibulariaceae (Bladderwort Family); Campanulaceae (Bellflower Family); Rubiaceae (Madder Family); Caprifoliaceae (Honeysuckle Family); Adoxaceae (Moschatel Family); Valerianaceae (Valerian Family); Dipsacaceae (Teasel Family).

Volumes 19: Published in 2005. Includes the following SK family: Asteraceae (Aster Family) in part.

Volumes 20: Published in 2005. Includes the following SK family: Asteraceae (Aster Family) in part.

Volumes 21: Published in 2005. Includes the following SK family: Asteraceae (Aster Family) in part.

Volume 22: Published in 2000. Includes the following SK families: Butomaceae (Flowering-Rush Family); Alismataceae (Water-Plantain Family); Hydrocharitaceae (Waterweed Family); Scheuchzeriaceae (Rannoch-Rush Family); Juncaginaceae (Arrow-Grass Family); Potamogetonaceae (Pondweed Family); Ruppiaceae (Ditch-Grass Family); Najadaceae (Pondweed Family); Zannichelliaceae (Horned Pondweed Family); Acoraceae (Calamus Family); Araceae (Arum Family); Lemnaceae (Duckweed Family); Commelinaceae (Spiderwort 
Family); Juncaceae (Rush Family); Sparganiaceae (Bur-reed Family); Typhaceae (Cat-tail Family).

Volume 23: Published in 2002. Includes the following SK family: Cyperaceae (Sedge Family).

Volume 24: Publication was scheduled for 2006/2007. Includes the following SK family: Poaceae (Grass Family) in part.

Volume 25: Published in 2003. Includes the following SK family: Poaceae (Grass Family) in part.
Volume 26: Published in 2002. Includes the following SK families: Liliaceae (Lily Family); Iridaceae (Iris Family); Smilacaceae (Greenbrier Family); Orchidaceae (Orchid Family).

The text of the treatments in published volumes can be accessed from the referenced FNA online site. ${ }^{3}$

1. MORIN, N. R. (ed.). 1987. Flora of North America News. Flora of North America Newsletter. Vol. 1, No. 1, p. 2.

2. FLORA OF NORTH AMERICA web site: http:/ /www.fna.org/publ-sched-details.shtml

3. E-FLORA web site: http://www.efloras.org/ flora_page.aspx?flora_id

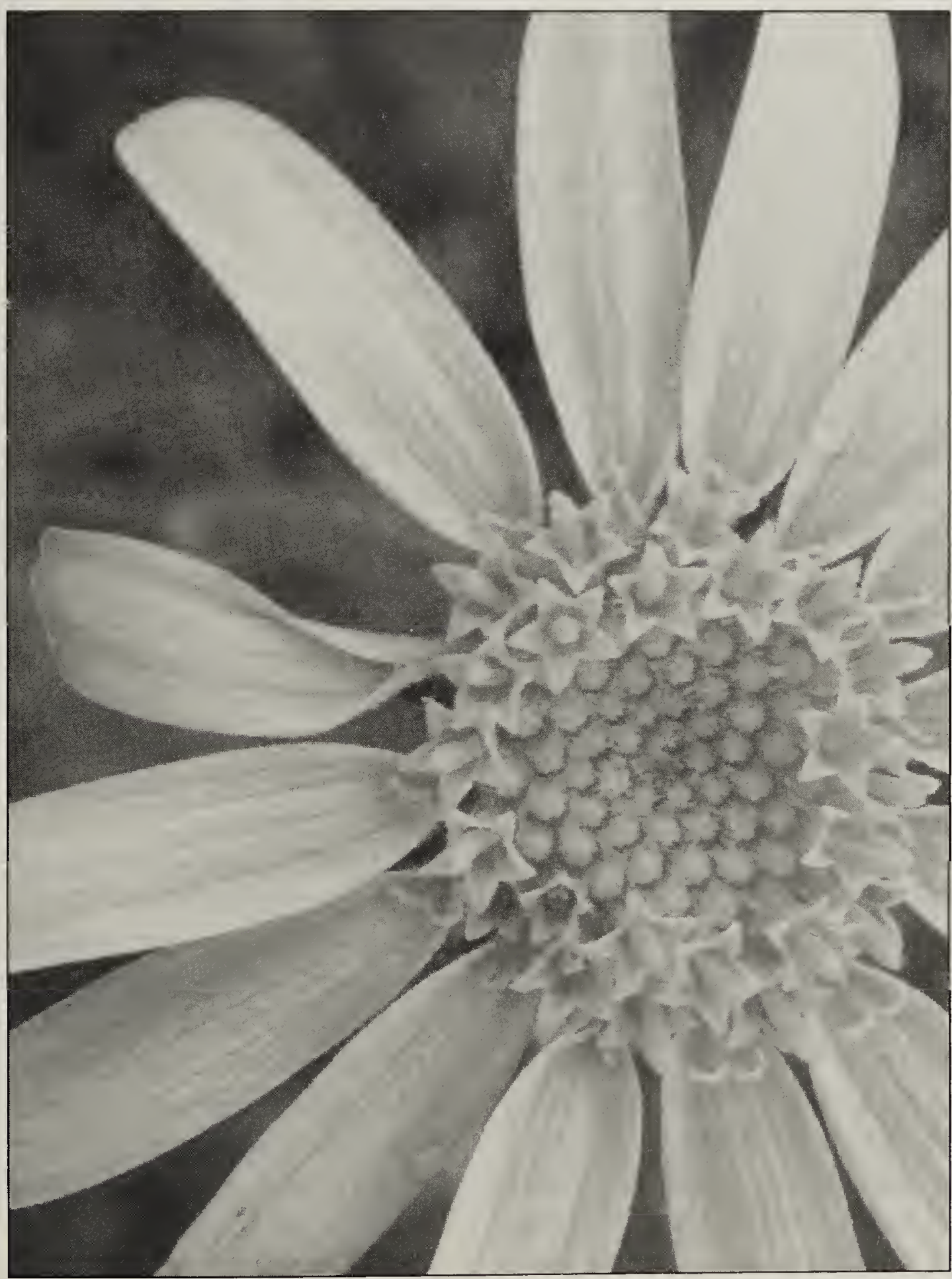

Joanne Marchand

Twin Arnica, Arnica sororia. 